\title{
The Dynamics of Philosophy "Ata One Ko Ata Penang" in The Customary Law of Inheritance in Manggarai from Pancasila Perspective
}

\author{
Adrianus Marselus Nggoro ${ }^{1}$, FX.Adji Samekto ${ }^{2}$ \\ \{adrianusnggoro@gmail.com ${ }^{1}$, samektoadjifx@gmail.com ${ }^{2}$ \} \\ ${ }^{1}$ ASAIHL, Doctoral Program of Law, Diponegoro University, 50239, Indonesia \\ ${ }^{2}$ ASAIHL, Facullty of Law, Diponegoro University, 50239, Indonesia
}

\begin{abstract}
There is currently no regulation of customary law status in the national legal system. The legacy of customary law in Indonesia is matrilineal, patrilineal, and parental. The problem is: (1) How is the dynamics of customary law practice inherited in Manggarai society which led to the dichotomy of the society's view of the status of the heirs? (2) Why is there a shift in legal practice about the position of boys and girls? (3) What is the model of Manggarai's customary law of construction?

The process of reviewing this paper is qualitative; a socio-legal approach, anthropological flow, with analysis: hermeneutics, symbolic interaction, dialectics, and phenomenology; the paradigm of Guba \& Lincoln Constructivism.

Discussion, philosophically, ideologically, and juridically, the customary law practice of the inheritance in Manggarai leads to justice that is a human being phenomenon. The traditional legal system of Manggarai heritage is a patrilineal, open opportunity to customary law system of parental inheritance.
\end{abstract}

Keywords: Dynamics; Customary Law; Inheritance; Pancasila

\section{Introduction}

The most current legal issue is "a new paradigm in legal pluralism in the global age as a moving and hegemonic law [1]. It is affirmed by Werner Menski that, "in legal pluralism theories there is no legal theory that can be allowed to dominate." This view is an inspiration for the phenomenon of legal pluralism, especially the existence of customary law of inheritance in the world today.

Some relevant research results: (1) A Minangkabau philosophy, "chick Gadang Indak Natalia" ("rooster laid no eggs"). The core of this philosophy is the Minangkabau adat heritage system refers to the principle of matrilineal descent (2) Though it seems to be argued that, in "plurality law theory that there is no legal theory that should be allowed to dominate." (3) Through research in Africa, there is a change of customary law provisions inheritance, that which owns plantation land is male and female. (4) Research in Ethiopia that the pluralism of customary law is the future of African law. Customary law is very limited to land ownership norms. (5) In Canada, legal restrictions have benefits for reducing inheritance inequality and improving social stability.

What is in Indonesia today? The national phenomenon there is no regulation of the legal system. In fact, in Indonesia, there is matrilineal, patrilineal, and parental. Therefore, the dynamics of customary law practices of inheritance are growing in the regions. This article discusses the phenomenon of customary law practice inheritance in Manggarai, East Nusa 
Tenggara Province. In Manggarai [2]" men are called insiders and women are called outsiders" ("ata one ko at pe'ang"). The meaning of this philosophy is "men as heir, a woman not as heir." However, the phenomenon today has two views of the dynamics of paradigm society: first, the old paradigm and second, the new paradigm (reforming society).

\section{Methodology}

\subsection{Method And Materials}

This study is using qualitative method; with a socio-legal approach; anthropological flow, through analysis of: hermeneutics, symbolic interaction, dialectics and phenomenology; with the paradigm of Guba \& Lincoln Constructivism (Theory and Paradigm of Social Research) [3], The location of where the research was conducted is in Manggarai, with data-collecting technique using Haberman's Theory that is data collection, data reduction, data display, and conclusion.

\subsection{Experimental Details of the results research in the form of the dynamics of customary law practice inheritance in Manggarai}

The Dynamic Phenomena Inheritance of Customary Law System Today is as follows: (1) The Conservative Society of Perspective (Patrilineal Society). Boys as family heirs. Girls can treasure parents through the giving of "wida" and "widening." If they do not have children, inheritance is given to adopted children and girls. If the family does not have children, then it can adopt a son as an heir. (2) View of the Society of Reformers. Boys and girls as heirs. Girls can treasure parents through inheritance, "wida" and "widang." "Wida" means "the gift of the parents to the daughter through custom and the daughter shall pay the money in the form of money or the form of a buffalo animal." While the meaning of the word "widang" is "giving of parent's property to the child without having to be paid by the child as receiver of the court.".

The form of practice of customary law system in Manggarai that was built by reformer citizens can be analyzed through various perspectives: (1) Philosophical Perspective. Philosophy of law contains elements of philosophy about human beings and the universe. The concept of Plato's law is justice, both for the state (public) and the individual; The measure of justice is human [4-7]. While Pancasila as the ground norm, as the basic principle of the Indonesian Republic "Staat-fundamental norm." This relevant legal concept as a ground norm is the norm for binding society [7,8]. (2) Ideological Perspective. The reformists championed the rights of girls as heirs to fulfill the expectations of Pancasila as an open and holistic ideology [9]. (3) Juridical Perspective. The reformists changing the face of Manggarai's inheritance law proves that customary law is not only normative but also unwritten/existing law. There are three basic values of law that is justice (philosophical value), certainty (juridical value), and usefulness (sociological value). Law for the man, and not man for the law [10,11]. Reformists support the concept of universally legal pluralism and the legal system (legal substance, legal structure, an[]8=.]d legal culture) in oral political communities in a global perspective $[12,13]$. Pancasila, as a source of national law and the Constitution of the Republic of Indonesia, includes the written and non-written law. In Article 18B of 1945, there is the legitimacy of the existence of customary law. The practice of inheritance law in Manggarai by reformists is also of relevance to the characteristics of customary law: (a) It has a common characteristic. (b) philosophical (c) is concrete, (d) Has a visual nature [14] . (4) Anthropological Perspectives of Law. The practice of inheritance law breakthrough by the 
inheritance law reformists in Manggarai demonstrates the intellectual freedom (mind) of human beings to create, and create innovation on culture (customary law). The man is the creator of culture $[13,15,16]$. Pancasila exists because of the proposition that God exists. If the man does not exist, then Pancasila also becomes absent $[11,16]$. (5) Perspectives of state law and human rights. Though it seems to be argued that, in "plurality law theory that there is no legal theory that should be allowed to dominate." The dynamics of customary law by the reformer society is rooted in justice, upholding human rights, democracy. The concept of Indonesian law is the welfare of human life [17]. A global issue on gender justice, because patriarchal culture dominates society. Patriarchal culture is similar to the perception of the emergence of "male city" as in South Africa and Rhodesia [11]:

\subsection{The Cause of Shift of Legal Practice of Customary Law Systems}

Some factors are causing the shift of customary law practices inherited by the reformists, namely: (1) Human Personality. A creative reformist is an embodiment of the development of rational philosophy. Change comes from the man himself. Hagen in McClelland's work asserts that personality is the main driver of change [7]. (2) The Nature of Law Itself (Berdeles Law). The practice of customary law by the reformists is a reflection of Pancasila, and the Constitution of Indonesia is dynamic and open. Law is a figure that continues to be interpreted and not final [13]. The law can break through indefinitely, locally, nationally, and internationally [1]. (3) A form in Book and Living Law. The 1945 Constitution of the Republic of Indonesia has a written and unwritten law [18]. The reformists changing the face of Manggarai's inheritance law proves that customary law is not only "ius scripts" but also "ius non-script"[19]. (4) Change of Time. The behavior of the reformists of Manggarai custom law is relevant to the Latin motto [20], "tempus mutantur, et nos muntamur in illid" ("time changes, and we also change in it"). The innovative citizen who innovates in the Manggarai custom law system describes a dynamic law. This is relevant to the view that a legal event at a given time is a series of events in different time dimensions [1]. Law changes due to being influenced by social reality. Holistic Law Science cannot work alone, but they have to form a connection with other disciplines.

\subsection{Proposed Construction Model of Manggarai's Customary Inheritance Law System}

The proposed model of Manggarai's customary law construction is the parental system, namely the heirs are (1) boys; (2) girls; (3) boys and girls. Moreover, how to inherit it are (1) natural inheritance; (2) through wida; (3) through the assembly.

\section{Conclusion}

Based on the preliminary findings of this study, the authors conclude as follows: (1) The practice form of inheritance law system by reformists is the parental system. (2) There are two factors for shifting the practice of customary law systems in Manggarai: internal factors(educational, occupational), and external factors (legal pluralism, globalization, glocalization, human rights, and democracy), and the dynamic nature of the law. (3) The traditional phenomenon of the legal system in Manggarai heritage is a patrilineal, open opportunity to customary law system of parental inheritance." 


\section{References}

[1] AW Bedner, S Irianto, Kajian Sosio-Legal. 2012.

[2] A.M.Nggoro. Budaya Manggarai Selayang Pandang. Nusa Indah, Ende; 2013. 160161,164-166 p.

[3] NK Denzin, SL Yvonna. Handbook of Qualitative Research. Yogyakarta: Pustaka pelajar; 2009.

[4] HJ Schmandt. Filsafat Politik: Kajian Historis dari Zaman Yunani Kuno Sampai Zaman Modern. Yogyakarta: Pustaka Pelajar; 2002. 64 p.

[5] Soetikno. Filsafat Hukum Bagian 1. Jakarta: Balai Pustaka; 2013. 16-21, 49 p.

[6] AM Nggoro. Philosophy "Mbaru Gendang" in Manggarai by Democracy Pancasila Perspective. In: The 2016 International Conference and Call for Papers (ICCP) UNS, The Administration of Justice, Universitas Sebelas Maret. Solo; 2016.

[7] FX.A.Samekto. Pergeseran Pemikiran Hukum dari Era Yunani menuju Postmodernisme. Jakarta: Konstitusi Press; 2015.

[8] H Kelsen. Teori Hukum Murni Dasar-dasar-dasar Ilmu Hukum normatif. Bandung: Nusa Media; 2016.

[9] M Kaelan. Liberalisasi Ideologi Negara Pancasila. Yogyakarta: Paradigma; 2015.

[10] A Busro. Pendidikan Tinggi Hukum di Masa Depan Penegakan Hukum di Indonesia. Yogyakarta: Thafa Media; 2014.

[11] MD Mahfud, H Sunariyati., Shidarta, B.L.Tanya, AF Susanto. Dekonstruksi dan Gerakan Pemikiran Hukum Progresif. Yogyakarta: Thafa Media; 2013.

[12] LM Friedman. Sistem Hukum Perspektif Ilmu Sosial. Bandung: Nusa Media; 2011.

[13] S Rahardjo. Negara Hukum yang Membahagiakan Rakyatnya. Yogyakarta: Genta Publishing; 2009.

[14] Soepomo. Pergulatan Tafsir Negara Integralistik Biografi Intelektual, Pemikiran Hukum Adat, dan Konstitusionalisme. Yogyakarta: Thafa Media; 2015.

[15] Koentjaraningrat. Bunga Rampai Kebudayaan, Mentalitas dan Pembangunan. Jakarta: Gramedia Pustaka Utama; 2007.

[16] S Wreksosuhardjo. Filsafat Pancasila Secara Ilmiah dan Aplikatif. Yogyakarta: Andi; 2004.

[17] S Irianto. Pluralisme Hukum Waris dan Keadilan Perempuan. Jakarta: Yayasan Pustaka Obor Indonesia; 2016.

[18] S. Rahardjo Ilmu Hukum. Bandung: Citra Aditya Bhakti; 2012.

[19] S Rahardjo. Pemanfaatan Ilmu-Ilmu Sosial bagi Pengembangan Ilmu Hukum. Yogyakarta: Genta Publishing; 2010.

[20] M. Sutrisno, P. Hendar, Teori-Teori Kebudayaan. Yogyakarta: Kanisius; 2013. 